https://doi.org/10.17816/MAJ191S1124-126

\title{
PRENATAL STRESS IN PROGRAMMING OF IMMUNE AND NEUROENDOCRINE SYSTEM DEVELOPMENT
}

\author{
L.A. Zakharova
}

Koltzov Institute of Developmental Biology, Russian Academy of Sciences, Moscow, Russia

\section{ПРЕНАТАЛЬНЫЙ СТРЕСС В ПРОГРАММИРОВАНИИ РАЗВИТИЯ ИММУННОЙ И НЕЙРОЭНДОКРИННОЙ СИСТЕМ}

\author{
Л.А. Захарова
}

ФГБУН «Институт биологии развития им. Н.К. Кольцова» РАН, Москва

\begin{abstract}
The analysis of published and original data demonstrates that prenatal stress induced by viral and bacterial infection, or changes in the physiological concentrations of neurohormones in early ontogeny can cause unfavorable impacts on the development of neuroendocrine and immune systems. In early pregnancy bacterial infection simulated by lipopolysaccharide in an experiment activates the maternal immune system, which enhances the synthesis of pro- and anti-inflammatory cytokines in both maternal and fetal organisms. Consequently, cytokines promote the secretion of a hormonal cascade in the hypothalamic-pituitary-adrenal system, thus eliciting the hormonal response to stress. Various stress factors during critical periods of neuroendocrine and immune system development modulate the epigenetic mechanisms controlling specific genes, which can affect the structure and function of these systems and increase the risk of various pathologies in the offspring.
\end{abstract}

Keywords: prenatal programming; proinflammatory cytokines; neurohormones; neuroendocrine and immune systems; long-term effects.

Представлен анализ собственных и литературных данных о негативном влиянии пренатального стресса, индуцированного вирусной или бактериальной инфекцией, или изменения физиологических концентраций нейрогормонов в раннем онтогенезе, на процессы развития нейроэндокринной и иммунной систем. На ранних сроках беременности инфекции, а в экспериментальных моделях бактериальный липополисахарид, активируют иммунную систему матери, в результате чего усиливается синтез про- и противовоспалительных цитокинов у матери и плодов. Цитокины, в свою очередь, активируют секрецию каскада гормонов в гипоталамо-гипофизарно-адреналовой системе и таким образом индуцируют гормональный стресс-ответ. Воздействия различных стрессогенных факторов в критические периоды развития иммунной и нейроэндокринной систем изменяют эпигенетические механизмы регуляции специфических генов, что может приводить к нарушениям процессов, контролирующих структуру и функции этих систем, и увеличивать риск возникновения различных патологических состояний у потомства.

Ключевые слова: ранний онтогенез; критические периоды развития; программирование иммунной и нервной систем; моноамины; ЛПС; провоспалительные цитокины; отдаленные последствия ЛА.

Various stress factors including viral and bacterial infection and changes in the physiological concentrations of neurohormones in early ontogeny can affect the molecular mechanisms controlling the formation and functioning of neuroendocrine and immune systems. The induced modifications can disturb programming of these systems' development that increase the risk of various pathologies in offspring [1]. The purpose of this study was to analyze original and published data of the reciprocal influence of neuroendocrine and immune systems on their development and functioning in normal physiological and pathological states. Experimental studies often use bacterial lipopolysaccharide (LPS), which is one of the most potent natural inducers of inflammation. LPS activates the maternal immune system, which enhances the synthesis of proand anti-inflammatory cytokines in both maternal and fetal organisms. Consequently, cytokines promote the secretion of a hormonal cascade in the hypothalamic-pituitary-adrenal system, thus elic- iting the hormonal response to stress [2]. The excessive production of proinflammatory cytokines leads to premature labor, various bone malformations, thymus atrophy, and impaired development of bone marrow. After maternal LPS exposure in early pregnancy the expression of factors involved in neurogenesis, neuronal migration, and axonal cone growth is suppressed [3]. The white matter injury increases the risk of cerebral palsy in newborns and typical manifestations of schizophrenia in adulthood [4]. The degradation of serotonergic neurons induced by LPS in the fetus is attributed to the increased levels of IL-6 and TNF $\alpha$ as well as to anxiety and depression in children. Dopamine deficiency leads to the development of dysthymia, Parkinson's disease, impairs learning [2, 5].

According to our data, the increased levels of IL-6, LIF and MCP-1 in rat maternal-fetal system after prenatal LPS exposure affect the development and functions of hypothalamic-pituitary-gonadal system [6]. Prenatal deficiency of serotonin causes 
the increase of cellular and humoral immune response, while the deficiency of dopamine and gonadotropin releasing-hormone $(\mathrm{GnRH})$ causes the suppression of cellular immune response in adult offspring [7]. The expression of different types of serotonin, dopamine and GnRH receptors in thymus is identified from the 16th day of embryonic development. The inhibition of monoamine and GnRH synthesis or blockades of their receptors by antagonists in fetuses change the pattern of
T lymphocyte maturation in the thymus of adult rats. Regulatory cytokines, which synthesis is increased in the fetal thymus under neurohormonal influence, are involved in the realization of these effects. Thus, early development is the period in which the epigenetic mechanisms providing for the adaptive plasticity of physiological systems are realized. Disruption of molecular mechanisms controlling the development during this period can induce long-term or irreversible changes in their functions.

\section{References}

1. Zakharova LA. Plasticity of neuroendocrine-immune interactions during ontogeny: role of perinatal programming in pathogenesis of inflammation and stress-related diseases in adults. Recent Patents on Endocrine, Metabolic \& Immune Drug Discovery. 2009;3:11-27.

2. Zakharova L. Perinatal stress in brain programming and pathogenesis of psychoneurological disorders. Biology Bulletin. 2015;42:12-20.

3. Liverman CS, Kaftan HA, Cui L,Berman NE. Altered expression of proinflammatory and developmental genes in the fetal brain in a mouse model of maternal infection. Neurosci Lett. 2006;399:220-225.

4. Girgis RR, Kumar SS, Brown AS. The cytokine model of schizophrenia: emerging therapeutic strategies. Biol. Psychiatry. 2014;75:292-299.

5. Wang S, Yan JY, Lo YK. Dopaminergic and serotoninergic deficiencies in young adult rats prenatally exposed to the bacterial lipopolysaccharide. Brain Res. 2009;1265:196-204.

6. Izvolskaia M, Sharova V, Zakharova L. Prenatal Programming of Neuroendocrine System Development by Lipopolysaccharide: Long-Term Effects. Int. J. Mol. Sci. 2018;19(11):e3695. https://doi.org/10.3390/ ijms19113695.

7. Mel'nikova VI, Izvol'skaia MS, Voronova SN, Zakharova LA. The role of serotonin in the immune system development and functioning during ontogenesis. Biology Bulletin. 2012;39(3):237-243. 